\title{
Determination of the Paleostress Orientations and Magnitudes for Missan Structures, Southeastern Iraq
}

\author{
Atheer Edan Khalil AL- Hachem ${ }^{a}$ \\ Mustafa Rasheed Salih Al - Obaidi ${ }^{b}$ \\ a,bDepartment of Geology, College of Science, University of Baghdad, Iraq \\ akhalil35155@gmail.com_mustafa.r.s.alubaidi@gmail.com
}

Submission date:- 8/4/2018 Acceptance date:- 10/6/2018 Publication date:- 5/12/2018

Keywords: Paleostress analysis, Right dihedral method, Mohr daigram, Missan, Iraq.

\begin{abstract}
The use of Right dihedral method and Mohr daigram method allow determination of the paleostress orientation and its magnitude in Missan structures, Southeastern Iraq. The principal stress orientations and its magnitudes have been determined by measure of the striation on the faults planes. The measurement of orientation of the principal stress was deduced by different graphical methods, the horizontal maximum principal stresses $(\sigma 1)$ magnitudes were $(3600$, $4360,4650,4750$ and 5700) bars, the horizontal intermediate principal stresses $(\sigma 2)$ magnitudes were $(1528$, $1842,1962.5,1998.5$ and 2390.5) bars and the vertical minimum principal stresses $(\sigma 3)$ magnitudes were $(544,676,725$, 753 and 919) bars. This study shows that area is located within unstable region, since the poles of measured faults lie in the area of reactivated faults in Mohr diagram.
\end{abstract}

\section{1- Introduction}

Most of the previous studies which have been carried out on the Folded Zone or other Zones of Iraq dealt with the orientation of the principal stresses [1], [2],[3], [4] and [5], but not with the shape of the stress tensor and the magnitudes of the fault planes paleostress.

Missan Structures (Amara, Noor, Buzurgan and Halfaya Structures),southeastern part of Iraq are located between latitudes $\left(31^{\circ} 30^{\circ}-32^{\circ} 40^{\circ}\right.$ North) and longitudes $\left(46^{\circ} 50^{\circ}-47^{\circ} 40^{\circ}\right.$ East), covering about (2900) $\mathrm{Km}^{2}$. See Figure (1). 


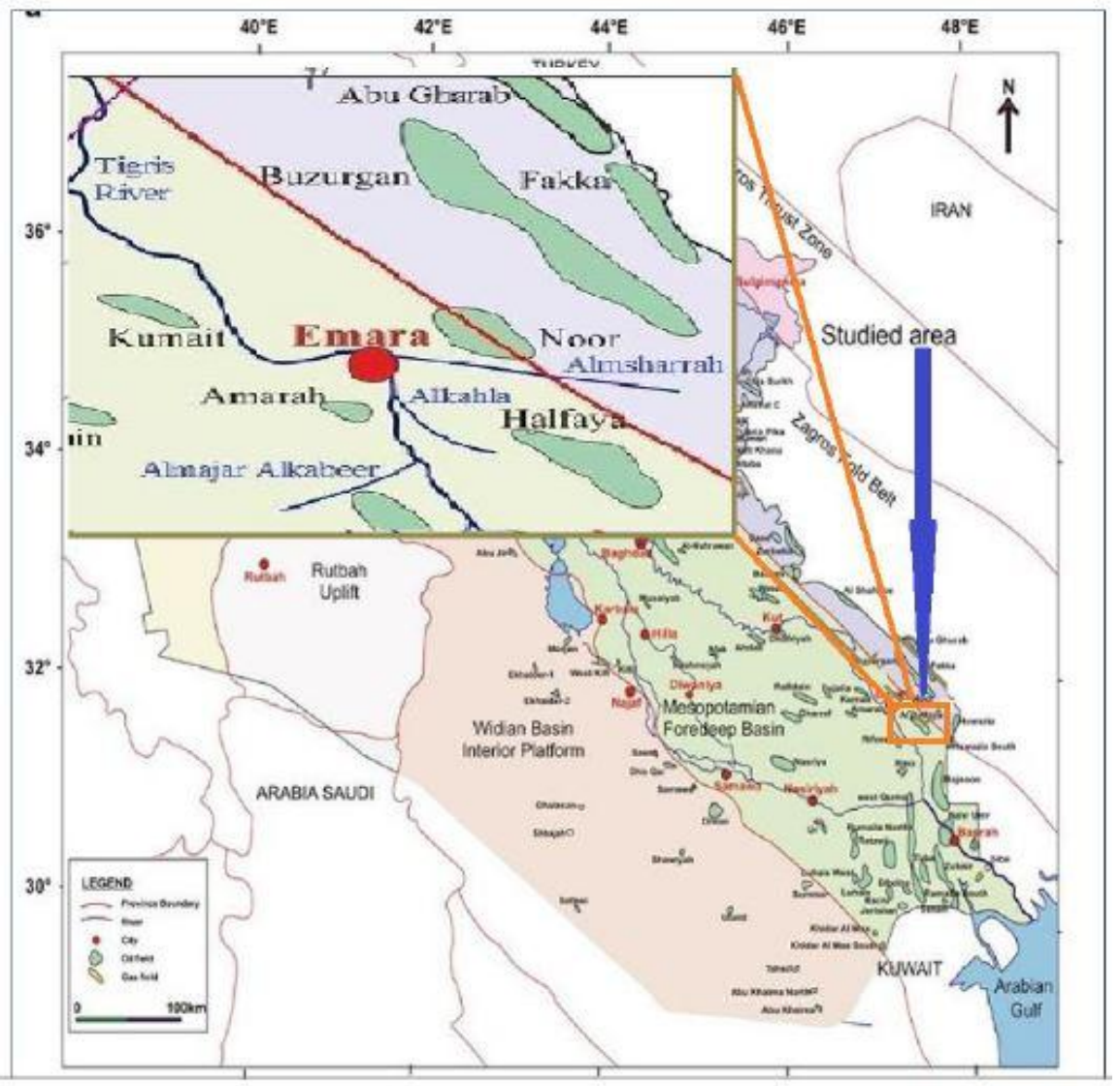

Figure (1) Location map of Missan Structures [6].

\section{2- Aims of the Study}

Aims of this study are:

1- To determine model parameters (Orientation, Stress ratio (R) and Magnitudes).

2- To analyze any relationship between there parameters and other factors (e.g. overburden, rock types and age of the stresses). This attempt has been made to carry out a regional analysis of the stress in folded and faulted areas in south of Iraq.

\section{3- Geological Setting}

Tectonically, the study area belongs to the unstable shelf represented by two Zones ; The Foothills Zones, along the Iraqi-Iranian international boundaries and the Mesopotamian Zone, more precisely, the former is represented by Hemrin Sub zone, whereas the latter by Tikrit-Amara Sub Zone [7] and [8].

Missan Structures (Amara, Noor, Buzurgan and Halfaya) locate at southeastern Iraq, Amara Structure is about (10) Km south western Amara city. Noor Structure is about (15) Km north eastern Amara city. Buzurgan Structure is about (40)Km to the north eastern Amara city. Halfaya Structure is about (35) Km to the South eastern Amara city. Amara and Noor structures are single anticlines run along a NW-SE trend, whereas Buzurgan and Halfaya structures are composed of two domes run along a NW-SE trend. See Figures (2,3,4 and 5).

Subsurface geology could be known through studying these drilled wells which cover the these structure and penetrate the Tertiary period deposits and most of the Cretaceous period deposits. Most of Tertiary depositions consist of calcic rocks and there are some formations consist units of clastic deposits and have big thickness, were deposited in shallow marine environment [6] and [9]. The formations from the oldest to the youngest of Cretaceous period starting from Yamama, Ratawi, Zubair, Shuaiba, Nahr Umr, Mauddud, Ahmadi, Rumaila, Mishrif ,Khasib, Tanuma, Sadi, Hartha and Shiranish, while the Tertiary period is represented by Aaliji , Jaddala ,Krikuk , Jeribe and Fatha ( Oil Exploration Company) [10]. 

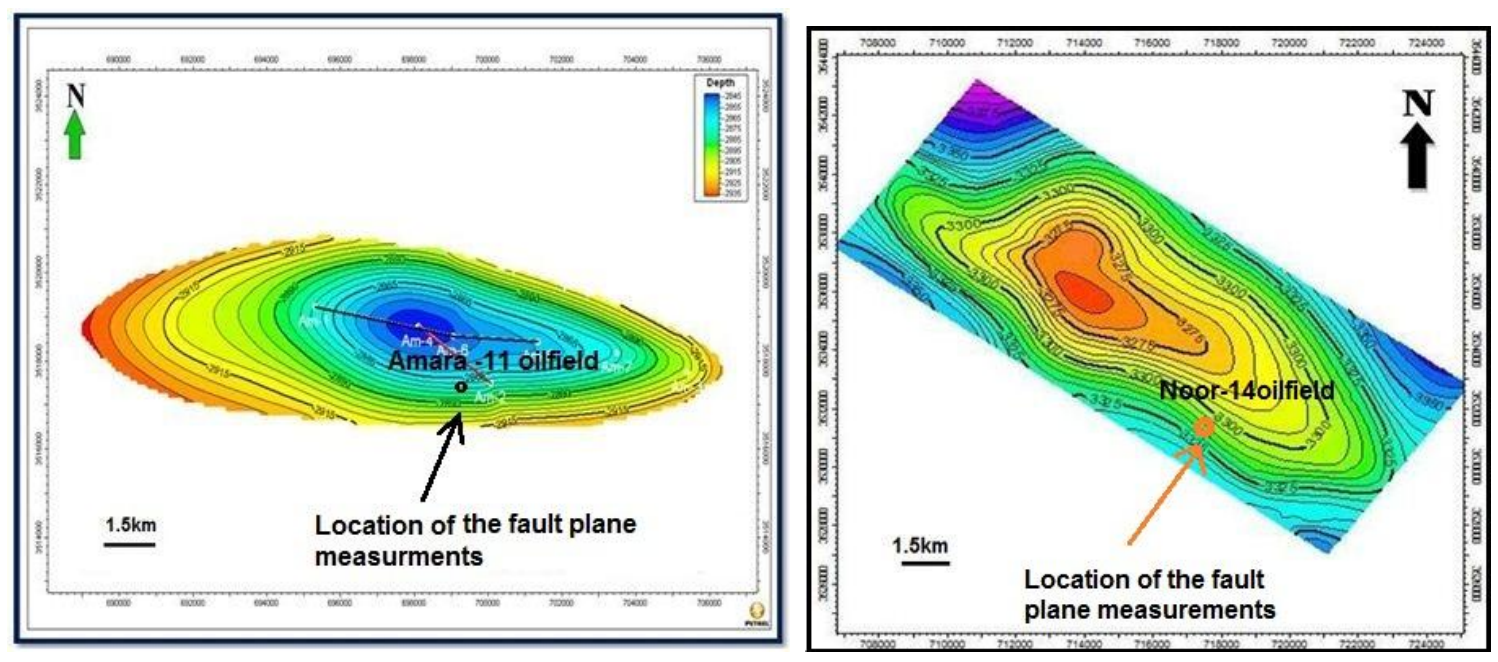

Figure (3) Structure contour map of Figure (2) Structure contour map of

Noor Structure [12]. Amara Structure [11].
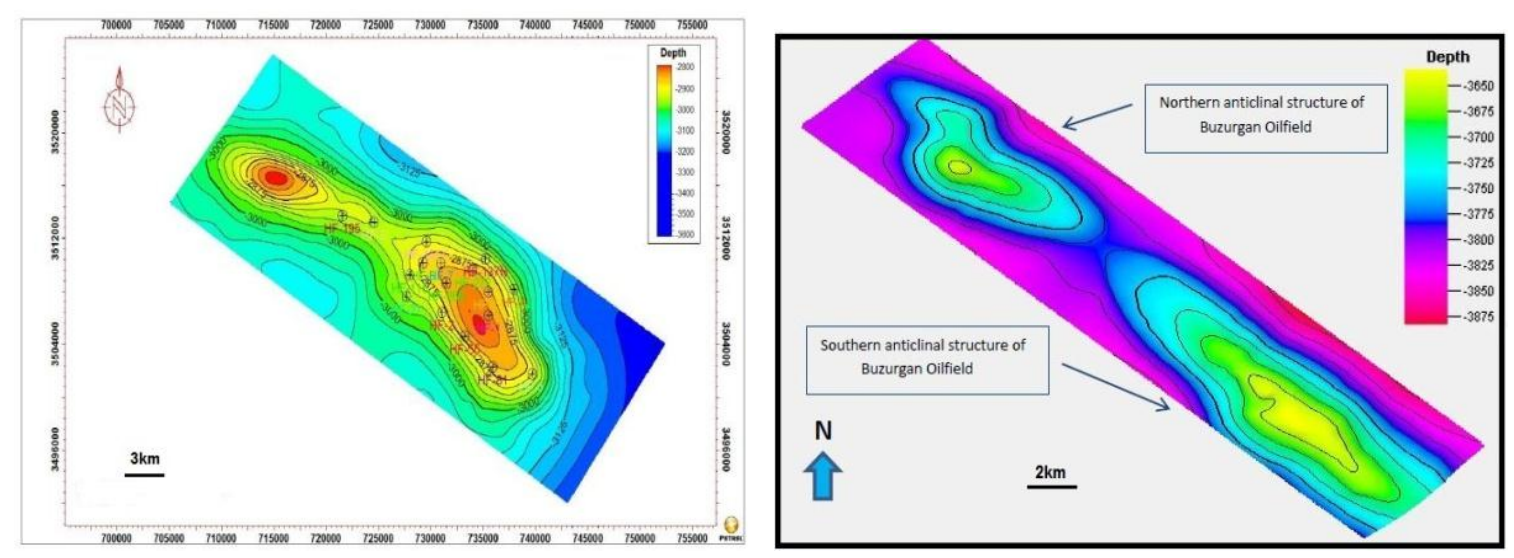

Figure (5)Structural contour map of Buzurgan Halfaya Structure [13]. Figure (4) Structural contour map of Structure [14]

\section{4-Methodology}

Many authors [3], [15], [16] and [17] used the fault slip data to yield the orientation of the principal stress axes and stress ratio $(\mathrm{R})$ and then take into account the depth of overburden.

[18] suggested that the lithostatic load gives value of the vertical stress. Experimental analyses shows and theoretical reasoning suggests that one of the principal stresses is generally vertical during the tectonic deformation.

In this study, Mohr daigram representation of the stresses in three dimensions from the basis of method used to check if the faults behaved as reactivated faults. When the occurrence of slip on discontinuities is controlled by the friction law [19], the plot points in the Mohr diagram should be found on or above the sliding line and beneath the failure envelope.

Several methods of fault plane striations analysis have been recently proposed for determining the axes of paleostress and deduce the directions and magnitude of the principal stress at the time faulting [20], [21] and [22]. Many authors [15], [16], [17],[18] and [23] have applied the reactivated fault model to estimate the magnitude of stresses. 


\section{1: Faults Analysis using Right dihedral method}

Depending on the fault planes and slickensides which were measured in the study area, strike of these fault planes was (130), and its dip $\left(40^{\circ}\right)$ in the east ( Cores measurements of Missan Structures).

Right dihedral method was used to determine directions of principal stresses axes $(\sigma 1, \sigma 2, \sigma 3)$ of the study areas, as follows the maximum principal stress $(\sigma 1)$ was horizontal and its strike $(058)$, the intermediate principal stress $(\sigma 2)$ was horizontal and its strike (328), and the minimum principal stress $(\sigma 3)$ was sub vertical its strike (148), and dip of these faults in a SW trending. See Figure (6).

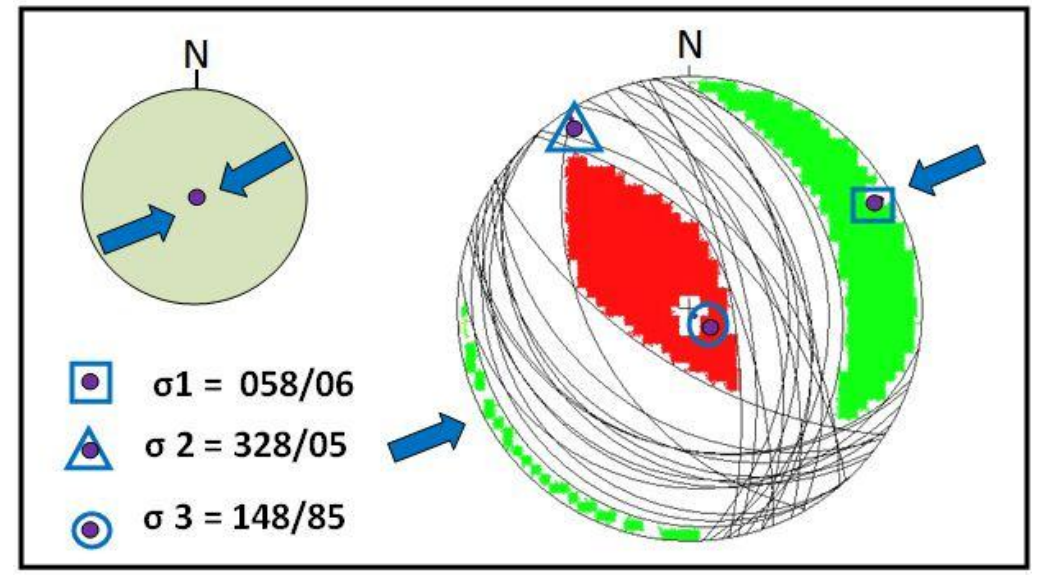

Figure (6) Right dihedral method shows distribution orientations of principal stress axes of the study area (GEOrient ver. 9.5, 2011).

The angles $(\alpha, \beta, \gamma)$ were measured between perpendicular plane $(\mathrm{N})$ on the fault plane and orientation of principal stress axes $(\sigma 1, \sigma 2, \sigma 3)$ respectively of all faults. Figure (7).

To determine stress ration (R) value of all faults, Bott,1959 law was applied [24].

$\mathrm{R}=\operatorname{taneIm}-\mathrm{I}^{2} \mathrm{n} / \mathrm{n}-\mathrm{n}^{3}$ [24].

Where:

$\mathrm{e}:$ is the pitch angle.

(I, $\mathrm{m}, \mathrm{n})$ : are cosine of the angles $(\alpha, \beta, \gamma)$ respectively. Table (1).

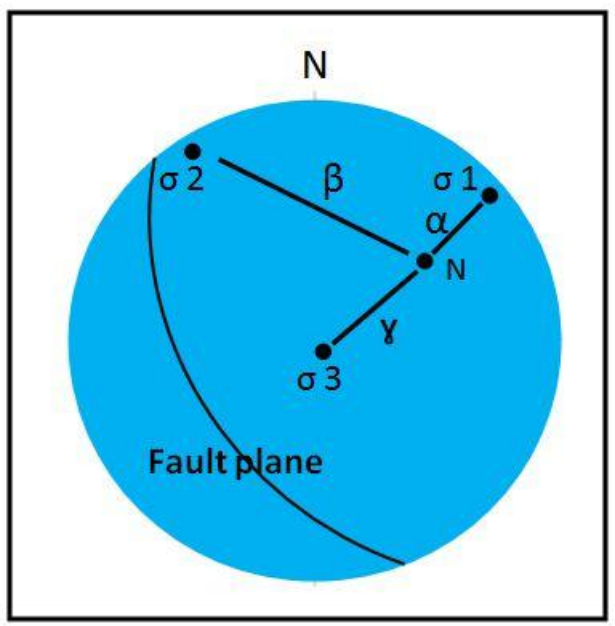

Figure (7) Shows method of angles calculation $(\alpha, \beta, \gamma)$ and orientations of the principal stress axes $(\sigma 1, \sigma 2, \sigma$ 3) $[25]$. 
Journal of University of Babylon for Pure and Applied Sciences,Vol.(26), No.(10): 2018

Table (1) Shows magnitude of the stress ratios $(R)$ for all faults of the study area.

\begin{tabular}{|c|c|c|c|c|c|c|c|}
\hline NO. & Fault plane & $\begin{array}{l}\text { Pitech } \\
\text { (ө) }\end{array}$ & $\tan (\theta)$ & $(\alpha)$ & ( $\beta)$ & $(\gamma)$ & $R=\tan \theta \underset{n^{3}}{\operatorname{Im}}-I^{2} n / n-$ \\
\hline 1 & $225 / 10$ & $70 W$ & 2.74 & 80 & 80 & 20 & 0.46 \\
\hline 2 & $230 / 15$ & $61 \mathrm{~W}$ & 1.8 & 85 & 75 & 20 & 0.19 \\
\hline 3 & $200 / 40$ & $60 W$ & 1.73 & 60 & 70 & 50 & 0.31 \\
\hline 4 & $214 / 50$ & $72 W$ & 3.07 & 45 & 75 & 60 & 0.76 \\
\hline 5 & $213 / 70$ & $70 W$ & 2.74 & 50 & 77 & 53 & 0.35 \\
\hline 6 & $204 / 30$ & $65 W$ & 2.14 & 60 & 76 & 44 & 0.22 \\
\hline 7 & $212 / 42$ & $55 W$ & 1.42 & 60 & 80 & 40 & 0.21 \\
\hline 8 & $220 / 35$ & $74 W$ & 0.83 & 67 & 60 & 53 & 1.48 \\
\hline 9 & $210 / 28$ & $68 W$ & 1.19 & 50 & 78 & 52 & 0.17 \\
\hline 10 & $190 / 24$ & $52 W$ & 1.27 & 75 & 70 & 35 & 0.75 \\
\hline 11 & 218/38 & $68 W$ & 2.47 & 55 & 75 & 50 & 0.39 \\
\hline 12 & $230 / 20$ & 69W & 1.96 & 75 & 80 & 25 & 0.33 \\
\hline 13 & $198 / 40$ & $72 W$ & 1 & 75 & 70 & 35 & 0.78 \\
\hline 14 & $240 / 55$ & $75 W$ & 3.73 & 37 & 80 & 63 & 0.63 \\
\hline
\end{tabular}

By using [26], the distribution of stress ratio ( R) values were calculated of all faults by Bott,1959 law, and calculated mean of the stress ratios $(R)$ value, which was $(\mathrm{R}$ mean $=0.5)$. See Figure $(8)$.

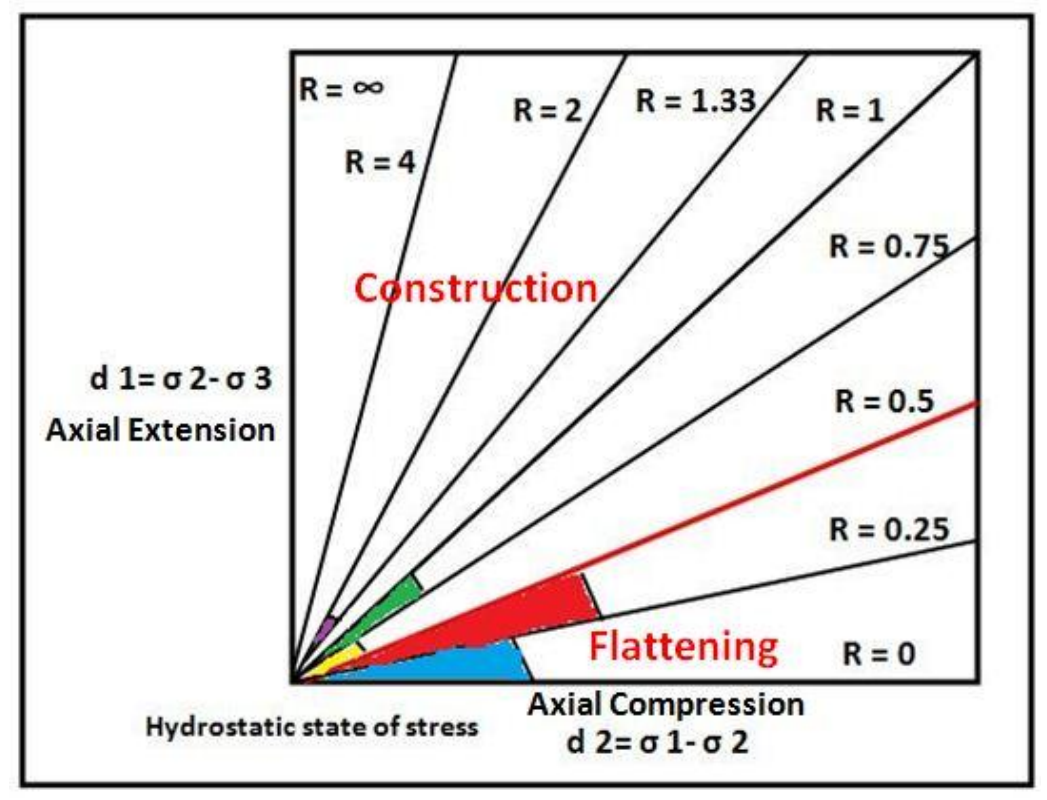

Figure (8) The distribution of stress ratio (R) values were calculated for all faults by [24] of Missan Structures on Lisle graph $(R$ mean $=0.5)$. 


\section{2: Determination of the paleostress magnitudes using Mohr diagram.}

In the study area, can be determined some of the tectonic and structural factors are not changed as follows:

a: Age of the studied formations refers to Cretaceous.

b: All rocks are sedimentary rocks.

c: All studied structures are subsurface.

There are other factors are change as density and thickness (overburden) of the rocks.

The lithostatic reference state is the simplest general stress model for the interior of the Earth. A rock volume with this condition cannot support differential stress over geologic time $(\sigma 1-\sigma 3=0)$, which means that its state of stress is described as a point on the horizontal axis of the Mohr diagram. This means that stress is independent of the orientation:

In this paper $(\sigma 3=\rho g z)$. The stress is, according to this model, completely controlled by the depth and density of the overlying rock column. For continental rocks, which have an vertical stress $(\sigma \mathrm{v})$ is close to the cap rock. Therefore, the vertical stress is given by: [21], [22] and [27].

The stress is, according to Mohr diagram, completely controlled by the depth and density of the overlying rock column. For continental rocks, which have an vertical stress $(\sigma v)$ is close to the cap rock. Therefore, the stress equal to the following equation:

$(\sigma \mathrm{v}=\rho \mathrm{gz})$

[26], [28] and [29].

Where:

$\rho=$ Density of the rock $\left(\mathrm{kg} / \mathrm{m}^{3}\right)$.

$\mathrm{g}=$ Acceleration of gravity $\left(\mathrm{m} / \mathrm{s}^{2}\right)$.

$\mathrm{Z}=$ Depth $(\mathrm{m})$.

Many authors studied cohesion strength of the sedimentary rocks and they showed the range of the cohesion strength values is between zero (0)bars no stick between the two blocks of faults and (100)bars [1], [2], [3], [15], [16], [18], [23],[28], and [30]. According to the compilations by many authors used internal friction angles $(\phi)$ for rocks are between $\left(25^{\circ}-45^{\circ}\right)$ [1],[2], [3],[16],[23], [31] and [32]. Two friction sliding lines angles of thrust faults have been measured experimentally by the authors for fault surfaces. These measured give angles, which are average of the minimum of friction sliding line angle is $\left(25^{\circ}\right)$ of smooth fault surfaces and the average of maximum of friction sliding line angle is $\left(35^{\circ}\right)$ of rough fault surfaces.

Thrust faults measurements were obtained from cores of Missan Structures of the study area (The orientation is assumption), depth and lithology of the rocks were obtained from Missan Oil Company (M.O.C), table -2, therefore, can be estimated vertical stress $(\sigma \mathrm{v}=\sigma 3)$, the depth $(\mathrm{z})$ from the table $(2),(\mathrm{g})$ equal $\left(9.8 \mathrm{~m} / \mathrm{s}^{2}\right)$, density of the rock can be calculated of the maximum, minimum and average of the rock limestone and shale which are (2720, 2000 and 2360) $\mathrm{kgm} / \mathrm{m}^{3}$ respectively.

Mohr diagram was drawn depending on the stress ratio $(\mathrm{R})$ magnitude $(\mathrm{R}=0.5)$ and the points (poles of the faults) were plotted depending on the angles $(\alpha, \beta, \gamma$, on the these circles [24], [25] and [34]. The plot points in Mohr diagram should be found above sliding line and beneath failure envelope. See Figure (9).

Figure (10) shows the relationship between the principal stresses axes. It shows that increasing with the depth due to its extension resulted from overburden. 
Journal of University of Babylon for Pure and Applied Sciences,Vol.(26), No.(10): 2018

Table (2) Shows depth and lithology of the rocks of the Missan Structures (M.O.C).

\begin{tabular}{|c|c|c|c|c|}
\hline NO. & Missan Structures & Formation & Lithology & Depth (m) \\
\hline 1 & Amara & Mishrif & Limestone & 2927 \\
\hline 2 & Amara & Mishrif & Limestone & 2928 \\
\hline 3 & Amara & Mishrif & Limestone & 2930 \\
\hline 4 & Noor & Mishrif & Limestone & 3348 \\
\hline 5 & Noor & Mishrif & Limestone & 3449 \\
\hline 6 & Amara & Mishrif & Limestone & 2937 \\
\hline 7 & Amara & Mishrif & Limestone & 2942 \\
\hline 8 & Noor & Mishrif & Limestone & 3365 \\
\hline 9 & Amara & Mishrif & Limestone & 2893 \\
\hline 10 & Amara & Mishrif & Limestone & 2941 \\
\hline 11 & Noor & Mishrif & Limestone & 3321 \\
\hline 12 & Noor & Mishrif & Limestone & 3323 \\
\hline 13 & Amara & Khasib & Limestone and shale & 2867 \\
\hline 14 & Amara & Khasib & Limestone and shale & 2828 \\
\hline
\end{tabular}
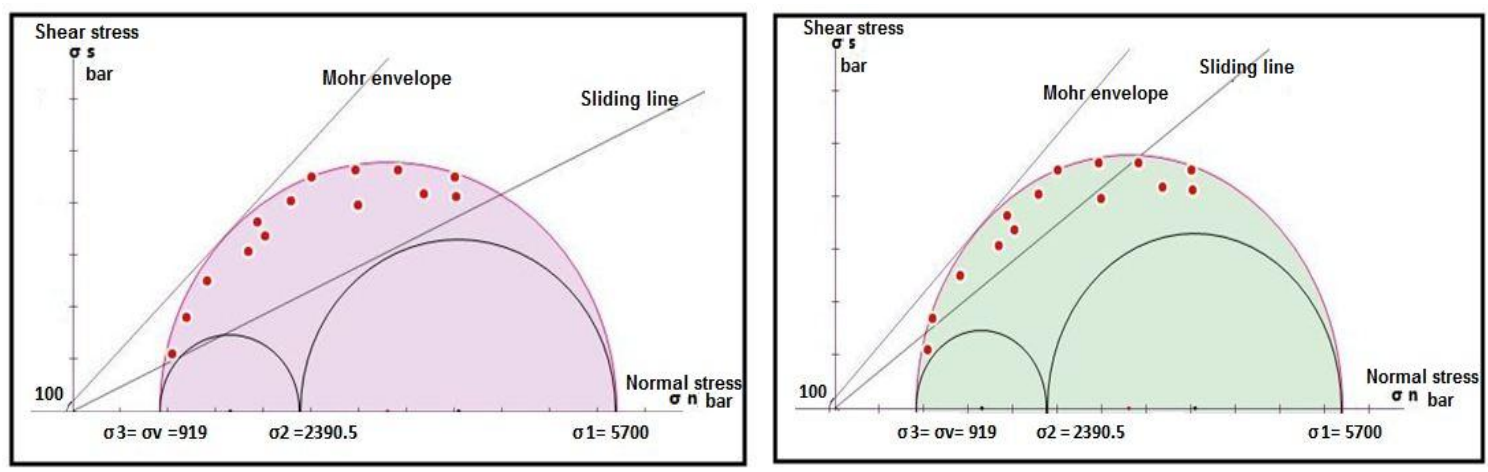

Figure (9a) Mohr diagram to calculate the magnitudes of the principal stresses in relation to two friction sliding lines of the study area (high density and high depth). 

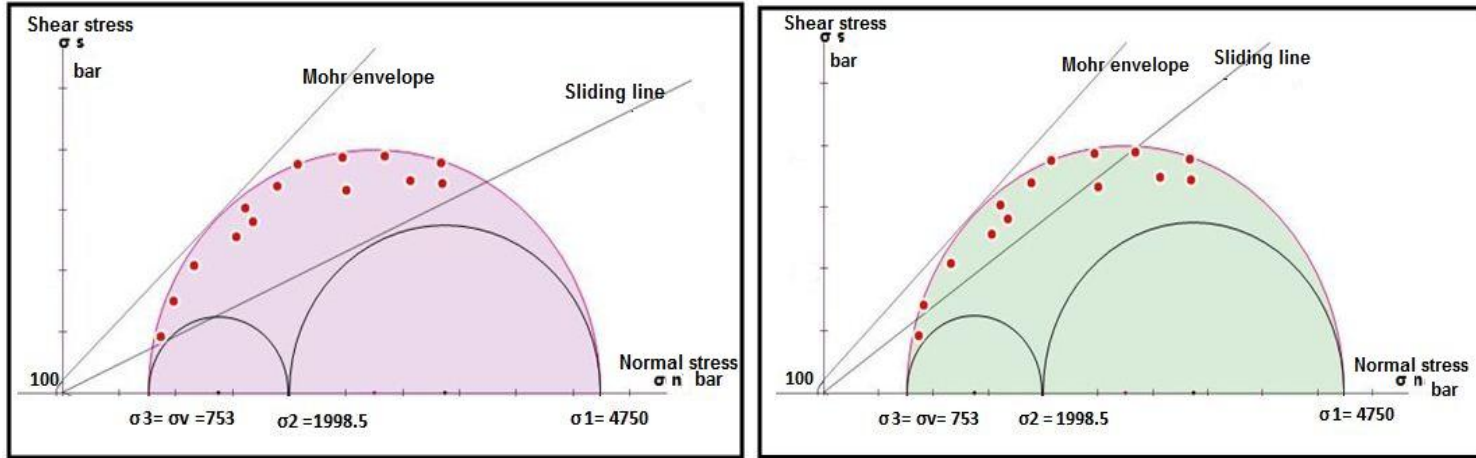

Figure (9b) Mohr diagram to calculate the magnitudes of the principal stresses in relation to two friction sliding lines of the study area (high density and low depth).
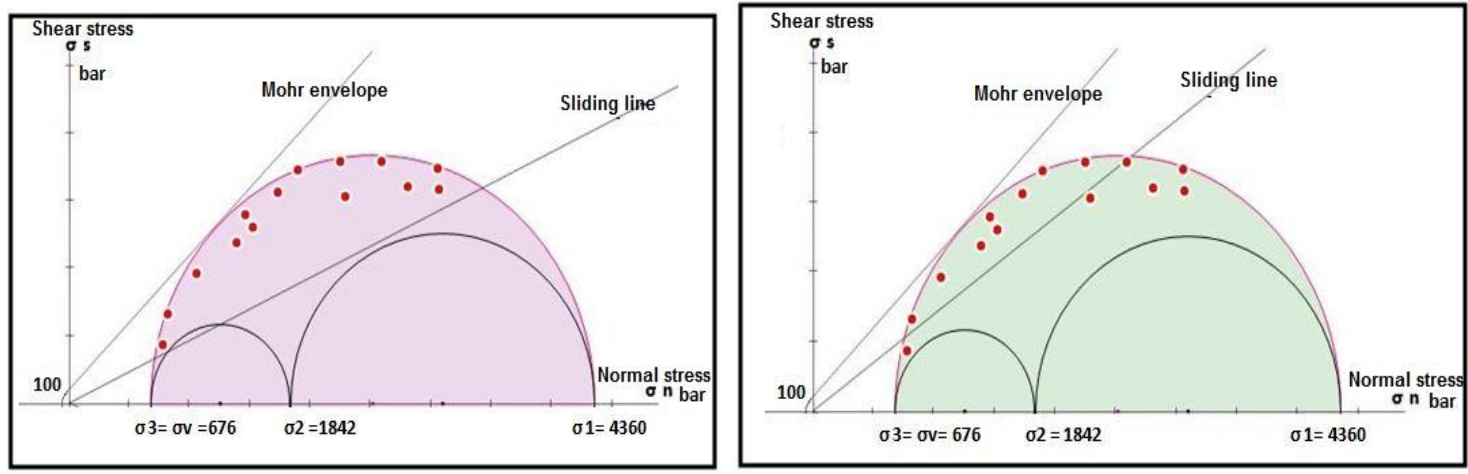

Figure (9c) Mohr diagram to calculate the magnitudes of the principal stresses in relation to two friction sliding lines of the study area (low density and high depth).
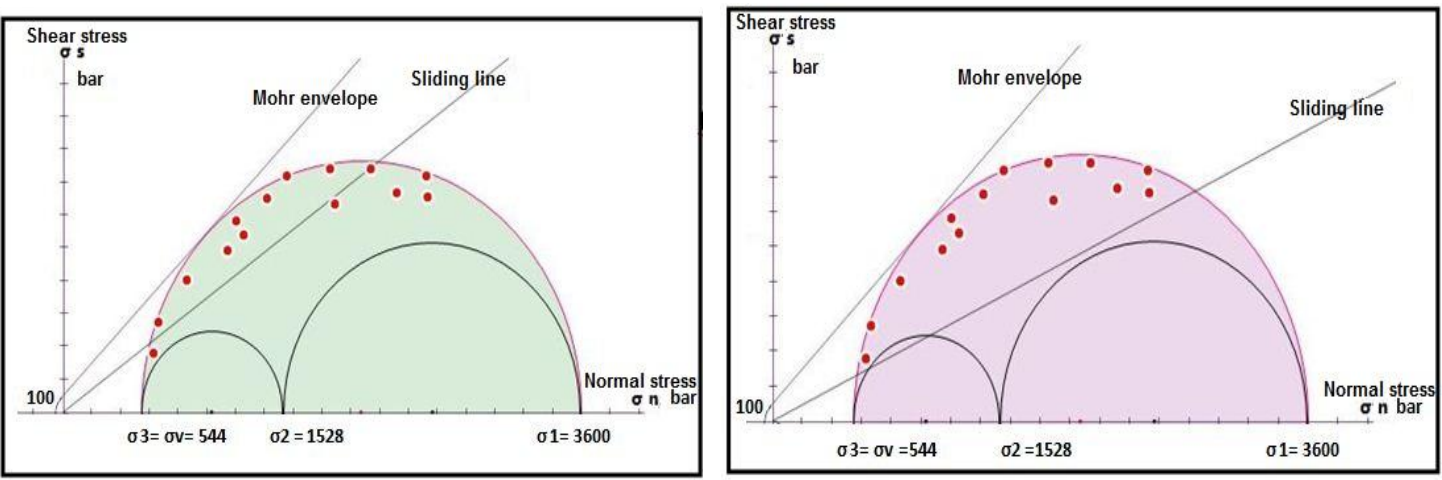

Figure (9d) Mohr diagram to calculate the magnitudes of the principal stresses in relation to two friction sliding lines of the study area (low density and low depth). 

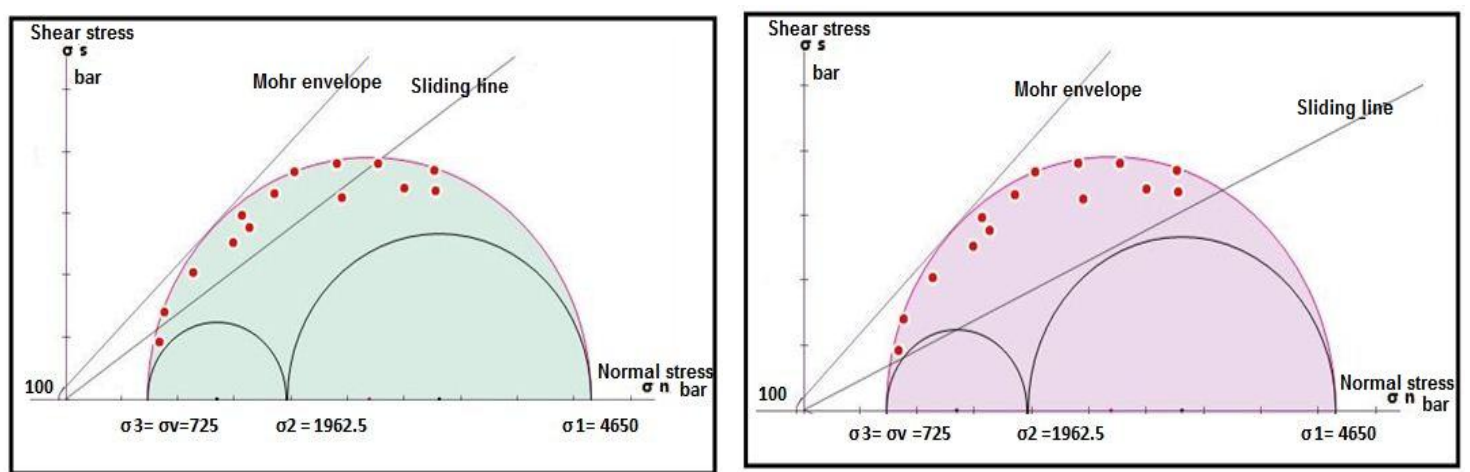

Figure (9e) Mohr diagram to calculate the magnitudes of the principle stresses in relation to two friction sliding of the study area (mean of the density and mean of the depth).

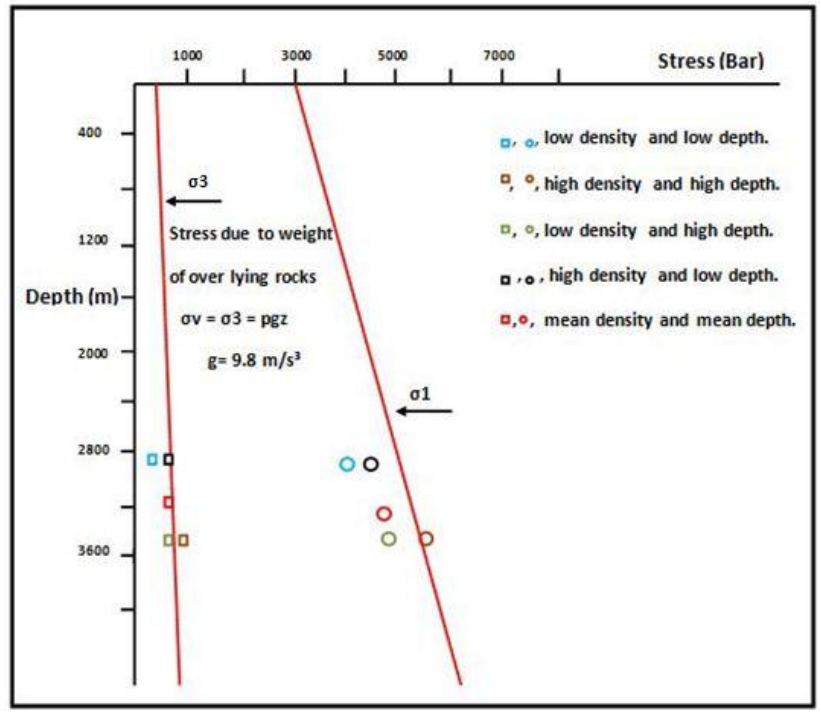

Figure (10) The relationship between the maximum and minimum principal stresses with the depth.

\section{5-Results of paleostress magnitudes determination.}

Orientation of stresses and the stress ratio ( R ), as discussed by [25], the maximum and minimum stresses ( $\sigma 1$ and $\sigma 3)$ are contained within right dihedral bounded by fault plane and imaginary plane which is perpendicular to the fault plane and to the direction of the maximum shear stress. Based on concepts similar to these geographical search procedure was illustrated by [20], [35] and [36] ,used individual faults to determine all possible orientations of ( $\sigma 1$ and $\sigma 3)$. Size of the fields containing $(\sigma 1$ and $\sigma 3)$ are reduced by superimposing of the dihedral stresses from other faults.

The result obtained by application of this method are summarized in Table (3). 
Table (3) Shows magnitudes of the principal stresses $(\sigma 1, \sigma 2, \sigma 3)$ of the study area.

\begin{tabular}{|c|c|c|c|c|c|c|c|c|c|}
\hline NO. & $\begin{array}{c}\sigma 1 \\
\text { bar }\end{array}$ & $\sigma 2$ bar & $\begin{array}{c}\sigma 3=\sigma \mathrm{v} \\
\text { bar }\end{array}$ & $\begin{array}{c}\text { Depth } \\
(\mathbf{m}) .\end{array}$ & $\begin{array}{c}\text { Density } \\
\text { Kg/m }\end{array}$ & $\begin{array}{c}\text { Hydrostatic } \\
\text { Pressure bar }= \\
(\sigma 1+\sigma 2+\sigma 3) \\
/ 3\end{array}$ & $\begin{array}{c}\text { Cohesion } \\
\text { Strength= } \\
(\sigma \text { 1- } \sigma 3) \\
\text { bar }\end{array}$ & $\begin{array}{c}\text { d 2 bar } \\
(\sigma 1-\sigma 2)\end{array}$ & d 1 bar = \\
$(\sigma 2-\sigma 3)$ \\
\hline 1 & 4360 & 1842 & 676 & 2828 & 2720 & 2292.5 & 3684 & 2518 & 1166 \\
\hline 2 & 5700 & 2390.5 & 919 & 3449 & 2720 & 3003.16 & 4781 & 3309.5 & 1471.5 \\
\hline 3 & 3600 & 1528 & 544 & 2828 & 2000 & 1890.66 & 3056 & 2072 & 984 \\
\hline 4 & 4750 & 1998.5 & 753 & 3449 & 2000 & 2500.5 & 3997 & 2751.5 & 1245.5 \\
\hline 5 & 4650 & 1962.5 & 725 & 3135.5 & 2360 & 2445.83 & 3925 & 2687.5 & 1237.5 \\
\hline
\end{tabular}

Thrust faulting in Missan structures involved NE-SW compression with $(\sigma 1)$ almost horizontal and extensional axes $(\sigma 3)$ is sub vertical and the intermediate axis $(\sigma 2)$ trend NW-SE horizontal. See Figure (11).

\section{6-Discussion}

Paleostress analysis results by Dihedral method and Mohr diagram show that the points (fault poles), ( reactivated faults) lie on or above two friction sliding lines and beneath failure envelope. Paleostress analysis indicates that the main paleostress field Late Cretaceous has been distinguished. The paleostress field was characterized by trending NE-SW, it includes thrust regime (compression regime). The study results showed the orientation of principal stress and its magnitudes are enough to produce or to reactivate faults in the study area. These stress magnitudes were not constant, and the stress ellipsoid was different. This difference refers to assumption to may be the difference of the stress fields, the depth variation (overburden thickness).

The high magnitudes of the principal stresses may be refer to the active tectonic event which led to the deformation of the area after Cretaceous and Tertiary age. 


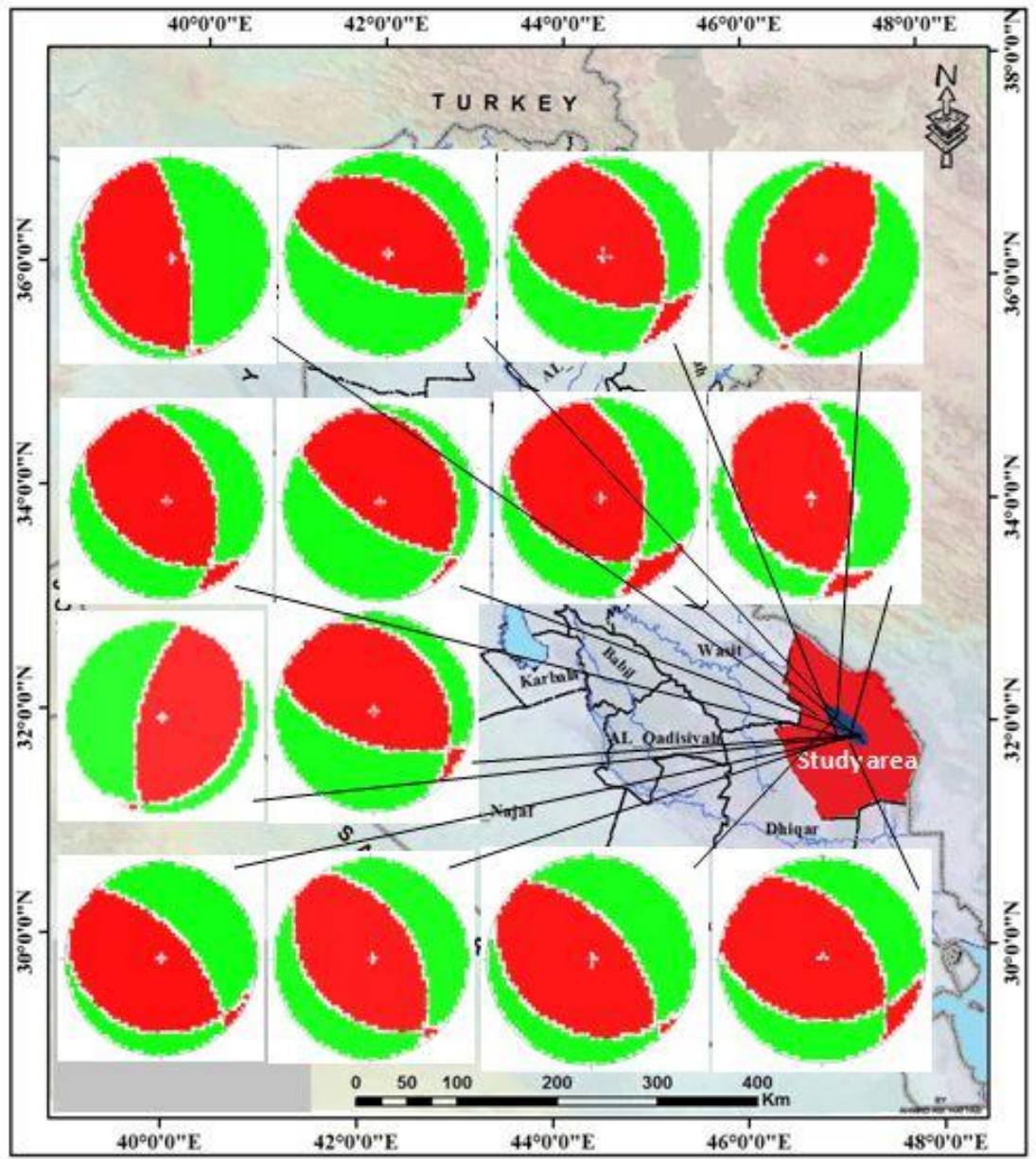

Figure (11) According to study Faults solution in a lower hemisphere equal- area projection, the red color represents $(\sigma 3)$, and the green color represents $(\sigma 1)$.

\section{7- Conclusions}

The fault structures of the studied area appear to have been produced by the NE- SW direction Alpine Orogenic compression. Paleostress analysis for fracture structures (Faults and Striations) indicated that the studied area was subjected throughout its geological history to a compression stresses which was perpendicular in orientation to the fold axis $(\mathrm{NE}-\mathrm{SW})$. Mohr diagram and Right dihedral methods suggest that area is affected by inhomogeneous deformation and shows a gradual change horizontal of these structures axes (This is a clear in in Buzurgan Structure axis is run a long a $\mathrm{N} 50^{\circ} \mathrm{W}$, Halfaya Structure axis is run a long a $\mathrm{N} 60^{\circ} \mathrm{W}$, Noor Structure axis is run a long a $65^{\circ} \mathrm{W}$ and Amara Structure axis is run a long a $\mathrm{N} 75^{\circ} \mathrm{W}$ trending) and thrust orientation. Distribution of the stress ratio magnitudes on Lisle graph [26].) show the stress mean ( $R$ ) less than one, $(R=0.5)$ that indicates shape of the stress was flattening $(\sigma 1 \geq \sigma 2=\sigma 3)$. These changes may be related to where they have developed not to when they have formed. The stresses magnitudes increasing refer to overburden thickness. This study shows that area is located within unstable region, since the poles of measured faults lie in the area of reactivated faults in Mohr diagram. 


\section{CONFLICT OF INTERESTS}

There are no conflicts of interest.

\section{References}

[1] M. R. Al- Obaidi, “ A Study of Geological Structures of Jabel Sinjar, “ M.S. thesis, Univ. of Baghdad, Baghdad, Iraq, 1978.

[2] M. R. Al-Obaidi, "Stress field determination (Orientation and Magnitudes) and their relation to structural trends and overburden thickness for Sinjar and Bashiqa structures, North of Iraq" , Journal of Science . Iraq, vol. 35, no. 2, pp. 365- 380, 1994.

[3] R. E. Handula, "Structural and stress analysis in the folded area north and northeast of Iraq, "M.S. thesis, Univ. of Baghdad, Baghdad, Iraq, 1997.

[4] A. A. Al- Diabat, M. R. Al-Obaidi and M. Atalla, "Magnitudes of the Paleostresses at the Eastern Rim of the Dead Sea Transform Fault”, Journal of Pure Sciences, vol. 30, no.1, pp.1-13, 2003.

[5] I. S. Al- Jumaily and H. G. Adeeb, "Mesofracture Analysis of Azmur Anticline North Eastern Iraq" , Iraqi Journal of Earth Sciences, vol. 10, no. 2, pp. 1-24, 2010.

[6] T.K. Al- Ameri, N. M. Al-Jubouri, J.I. Murtadha and R. E. Al-Azzawi, "Hydrocarbons Generation Potential of the Jurassic- Lower Cretaceous Formation, Ajeel Field, Iraq", Arab Journal of Geoscience Springer, 6, pp.3725$3735,2013$.

[7] J. A. Al- Khadimi, V. K. Sissakian, A. S. Fattah and D. B. Deikaran, Tectonic map of Iraq, (Scale: 1:1 000000) S. E. of Geological Survey and Mining, Iraq,1996.

[8] S. Z. Jassim, and J. C. Goff, Geology of Iraq. Published by Dolin, Moravian, Museum, Brno, Checa, 2006.

[9] T. K. Al- Ameri, J. Pitman, M. E. Naser, J. Zumberge and H. A. Al-Haydari, "Programed oil generation of the Zubair Formation, Southern Iraq oil fields", Arab Journal of Geoscience, vol.4, 2010.

[10] Oil Exploration Company (O.E.C.) Structural map of southern Iraq, Geological department, 2013.

[11] B. A. Al- Baldawi, "Formation Evaluation of Al-Mishrif Reservoir, Amara Oil Field, South Eastern Iraq," M.S, thesis, Univ. of Baghdad, Baghdad, Iraq, 2012.

[12] A. A. Al- Tai, "Age and Environment Assessment in Noor Oil Field Oil-Source Parameters, from Missan Governorate Southern Iraq,” M.S. thesis, Univ. of Baghdad, Baghdad, Iraq, 2013.

[13] A. D. Al- Mosawy, “ 3DIntegrated Geological Modeling of Mishrif Formation in Halfaya Oil Field," M.S. thesis, Univ. of Baghdad, Baghdad, Iraq, 2014.

[14] L. Y. Al-Shabender, "Geophysical Techniques and 3D Petrophysical the Modeling Used to study the Characterization of Mishrif Formation in Buzurgan Oil Field, southeast Iraq," M.S. thesis, Univ. of Baghdad, Baghdad, Iraq, 2014.

[15] M. R. Al- Obaidi, The structural analysis of the Trimsaran, NW, part of the South Wales Coalfield. Ph. D. dissertation, Wales Univ., Wales, London, 1990.

[16] M. R. Al- Obaidi and A. M. Al-Kotbah, "The magnitudes of the paleostresses of Yemen Faults in the sedimentary cover", Faculty of Science Bulletin, vol.16, pp. 95-109, 2003.

[17] A. A. Al- Diabat, "Paleostress Analysis of the Cretaceous - Tertiary Rocks in Central Jordan", Journal of Pure Sciences, vol. 34. no. 2, pp. 192- 200, 2007.

[18] J. Angelier, " From orientation to magnitudes in paleostress determinations using fault slip data", Journal of Structural Geology, vol. 11, pp. 37-50, 1989.

[19] J. C. Jaeger, Elasticity, Fracture and Flow. Third edition. Methuen London, 1964.

[20] J. Angelier and P. Mechler, "Sur une method graphique de recherche descontraintes principales egalement utilizable en tectonique et en seismologie: Iamethod de diedres droits”, Bull. Soc. Geol. Far.7, pp. 1309- 1318, 1977.

[21] R. J. Lisle, “ Principal stress orientations from faults, an additional constraint”, Ann. Tectonicae, vol.1, pp. 155158, 1987.

[22] R. F. Berry, " The history of movement on the Henty fault zone, western Tasmania: An analysis of fault strations ", Ast. Journal of Earth Science, vol. 36, pp. 189-205, 1990. 
[23] W. Sassi and E. Carey - Gailhardis, “ Interpretation mechanique du hlissent surles tailles: Introduction dun critere de frottement “, Annales Tectonicae, vol. 1, pp. 542- 544, 1987.

[24] M. H. Bott, “The mechanics of oblique slip faulting “, Geol. Mag., vol. 96, pp. 109-117, 1959.

[25] E. W. Spencer, Introduction to the structure of the earth. New York, McGraw- Hall, 1969.

[26] J. Lisle, " The representation and calculation of the deviatoric component of the Geological stress tenser", Journal of Structural Geology, vol. 1, pp. 317-321, 1979.

[27] H. Fossen, Structural Geology: United States of America, Cambridge University Press, third edition, 2012.

[28] J. Suppe, Principle of structural geology. Prentile- Hall, Inc. Engle wood cliffs, New Jersey, 1985.

[29] B. A. Van der Pluijm and S. Marshak, Earth Structure: An Introduction to Structural Geology and Tectonics, second edition, WCB/ McGraw-Hill, USA, 2004.

[30] R. G. Park, Geological structures and moving plates. Chaoman and Hall, New York, 1988.

[31] A . Capigian and A. Faisal, A. Engineering evolution of Upper Euphrates Site. State establishment of Geological Survey and Mining.(Geosurve), Baghdad, Iraq, 1995.

[32] E. Hoeck. And J. W. Bruy, Rock slope engineering. The institution of mining and metallurgy, London, 1977.

[33] N. Price, Fault and Joint Development in Brittle and Semi- Brittle Rock: Pergamon Press, Oxford, 1966.

[34] P. Mckenzie and J. Jacksone, " The relationship between fault plane solution and the directions of the principal stresses “ Bull. Seismol. Am., vol. 59, no.2, pp. 591- 601, 1969.

[35] I .S. Al-Jumaily, H. G. Adeed, R. K. Al- Hamdani and M. S. Dawlat, "Structural Analysis and Tectonic Interpretation of Brittle Failure Structures at Perat Anticline- NE- Iraq", Iraqi National Journal of Earth Science, vol. 12, no. 2, pp. 17-42, 2012.

[36] B. Benford. B. Tikoff and C. DeMets, “ Interaction of reactivated faults within a restraining bend: Neotectonic deformation of southwest Jamaica", Geological Society of America, vol. 7, no.1, pp. 21-39, 2014.

\section{تحديد اتجاه وقيم الاجهاد القديم في تراكيب ميسان، جنوب شرق العراق}

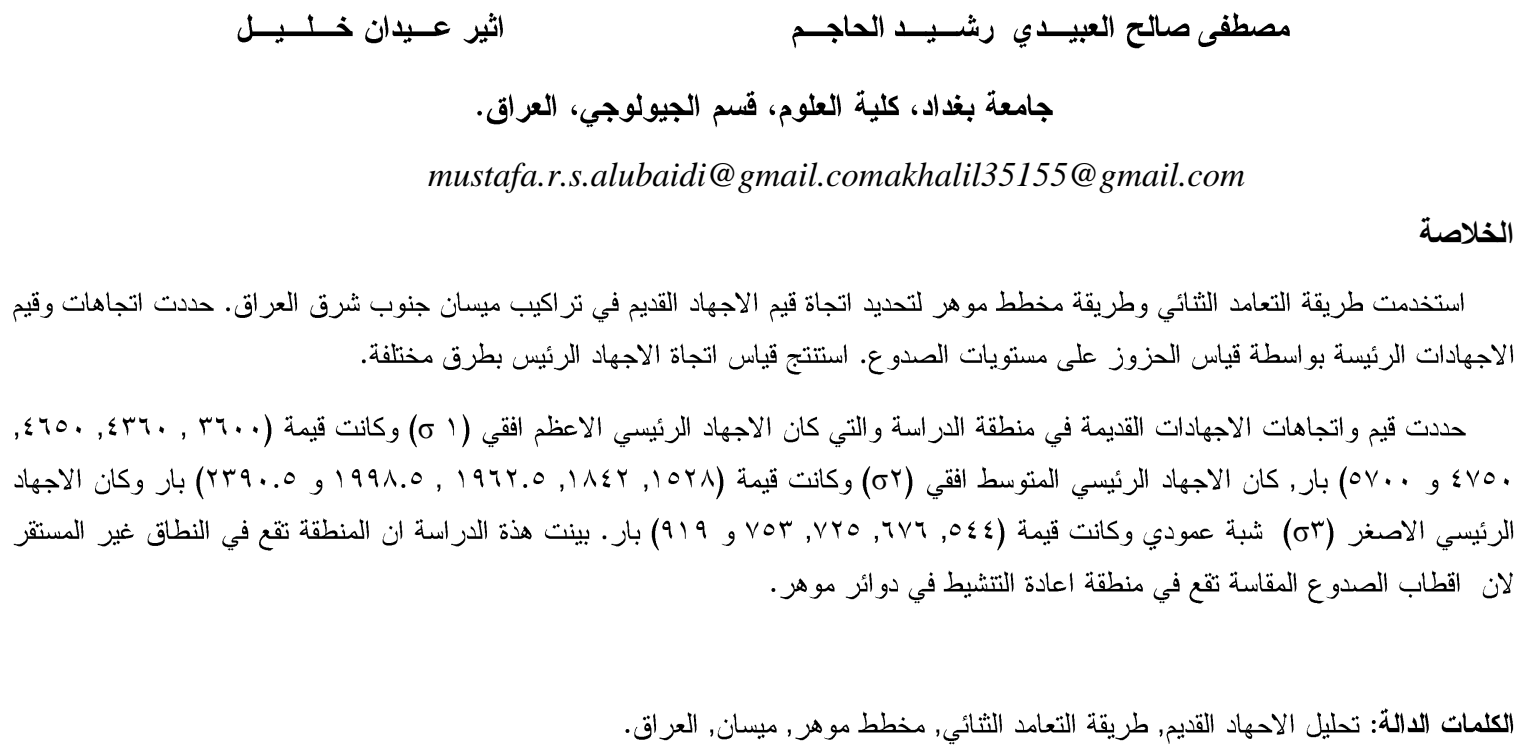

